\title{
Distant metastases of a squamous cell carcinoma of the tongue in peripheral skeletal muscles and adjacent soft tissues Ralf Smeets*1,2, Maurice B Grosjean ${ }^{3,4}$, Max Heiland ${ }^{5}$, Dieter Riediger ${ }^{1}$ and Oliver Maciejewski ${ }^{1}$
}

\begin{abstract}
Address: ${ }^{1}$ University Hospital Aachen, Department of Oral and Maxillofacial Surgery, Aachen, Germany, ${ }^{2} \mathrm{RWTH}$ Aachen University, Interdisciplinary Center for Clinical Research (IZKF) 'BIOMAT', Aachen, Germany, ${ }^{3}$ University Hospital Basel, Department of Reconstructive Surgery, Division of Cranio-Maxillofacial Surgery, Basel, Switzerland, ${ }^{4}$ University of Basel, Center of Multidisciplinary Research in CranioMaxillofacial Surgery "Hightech-Forschungs-Zentrum" (HFZ), Basel, Switzerland and "5niversity Hospital Hamburg-Eppendorf, Department of Oral and Maxillofacial Surgery, Hamburg, Germany

Email: Ralf Smeets* - rasmeets@ukaachen.de; Maurice B Grosjean - mbgrosjean@gmail.com; Max Heiland - heiland@uke.uni-hamburg.de; Dieter Riediger - driediger@ukaachen.de; Oliver Maciejewski - omaciejewski@web.de

* Corresponding author
\end{abstract}

Published: 26 March 2008

Head \& Face Medicine 2008, 4:7 doi:10.1 186/1746-160X-4-7

This article is available from: http://www.head-face-med.com/content/4/I/7

(c) 2008 Smeets et al; licensee BioMed Central Ltd.

This is an Open Access article distributed under the terms of the Creative Commons Attribution License (http://creativecommons.org/licenses/by/2.0), which permits unrestricted use, distribution, and reproduction in any medium, provided the original work is properly cited.
Received: 21 November 2007

Accepted: 26 March 2008

\begin{abstract}
A 66-year-old female patient was admitted to our department with a large tumor of the tongue measuring $10 \mathrm{~cm}$ in diameter. The tumor occupied nearly the entire oral cavity and showed exophytic and ulcerative areas. Histological analysis revealed a low grade squamous cell carcinoma (SCC) of the tongue. Bilateral enlarged cervical lymphatic masses were also present. The extent of the tumor infiltration was assessed by fluoro-2-deoxy-glucose-positron emission tomography (PET) scans showing an elevated activity of the tracer corresponding to the assumed cervical metastases. Additionally, pulmonary metastases were identified. Contrast enhanced computed tomography (CT) scans showed metastases in the soft tissues of the abdomen, legs and arms. Foci of distant metastases were found in the left upper anterior thoracal wall, near the intraabdominal portion of the aorta, near the right iliac crest and in both the right vastus medialis- and adductor magnus muscles. The final diagnosis was a T4N3MI(G3)(C3) SCC of the tongue with multiple distant thoracal, abdominal and intramuscular metastases. The survival expectancy was five weeks, and the patient finally deceased by cardiopulmonary complications.
\end{abstract}

\section{Background}

Patients suffering from a squamous cell carcinoma (SCC) of the head and neck region with distant metastases generally have a very poor prognosis [1]. Distant metastases typically manifest themselves in the lung, bones, liver and skin. Only few articles have been reported on a different localization of distant metastases. Moriya et al. (2004) recently reported on a patient suffering from a cardial metastasis of an oral SSC together with additional metastases in the liver, lung, spleen and kidneys [2]. A distant metastasis in the gluteal muscle of a 65 -year-old patient suffering from a SSC of the larynx has been recently described [3]. Oo et al. (2004) have identified three patients with metastases in the axillary lymph nodes over a period of 20 years [4]. In these three case reports, the primary malignoma were identified as carcinomas within a pleomorphous adenoma of the parotideal gland, a SCC of the tongue and a SCC of the anterior floor of the mouth, respectively. Mess et al. (1986) have reported on distant metastases which were localized in the carpal bones of the 
midhand and in the bones of the foot [5]. As to our knowledge, no case has been reported up to date on the manifestation of distant metastases of a SCC in the soft tissue of the extremities.

In summary, we report on a 66-year-old female patient who suffered from a terminal SCC of the tongue with multiple distant metastases which were localized mainly in the peripheral skeletal muscles and adjacent soft tissues of the lower extremities. Furthermore, we show an overview on the current literature on metastases originating from head and neck tumors [Table 1].

\section{Case presentation}

A 66-year-old woman was admitted with the symptoms of acute dyspnoe, orthopnoe and progressive dysphagia. The inspection of the oral cavity revealed an extensive lesion of the tongue (Fig. 1) with areas of exophytic growth of the tumor as well as a large ulcus located at the dorsal part of the tongue. This large tumor of the tongue occupied nearly the whole oral cavity and the anterior part of the tongue's margin clearly showed biting traces. These inspectatory findings were accompanied by a respective halitosis. Both the general and nutritional status of the patient were clearly reduced with a body mass index (BMI) of $15.6 \mathrm{~kg} / \mathrm{m} 2$ (body weight of $40 \mathrm{~kg}$ and height of $1.60 \mathrm{~m}$ ). The medical examination revealed the presence of bilateral large cervical conglomerates of lymph nodes that sonographically measured $6 \mathrm{~cm}$ in diameter. An acute obstruction of the upper airway by the tumor mass could

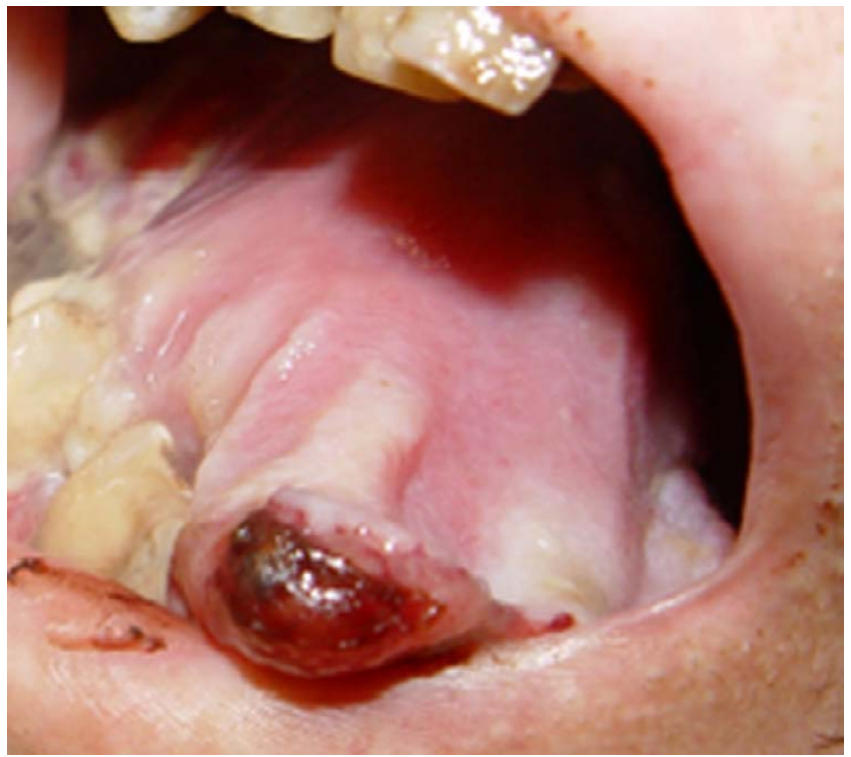

\section{Figure I}

Intraoral photography: Tumor of the tongue with bite marks at the margin, filling the oral cavity.

be excluded by native computed tomography (CT) imaging of the neck and therefore a tracheotomy was not performed. At admission, the diameter of the tumor was already greater than $10 \mathrm{~cm}$ (Fig. 2). At the same time, a bioptic tissue probe was analyzed histologically and revealed a low grade differenciated (G3) SCC (Fig. 3).

Table I: Survey of the literature

\begin{tabular}{|c|c|c|}
\hline Authors & Cases & Results (localization of distant metastases in \%) \\
\hline Probert et al. 1974 [24] & 96 Patients with SCC, $31 \%$ OSCC & $\begin{array}{l}\text { lung } 65 \% \text {, bone } 25 \% \text {, liver } 24 \% \text {, skin } 14 \% \text {, brain } 13 \% \text {, adrenal } 8 \% \text {, heart } \\
7 \% \text {, kidney } 6 \% \text {, peritoneum, mediastinum and soft tissue each } 5 \% \text {, } \\
\text { esophagus } 4 \% \text {, spleen } 3 \% \text {, bone marrow } 3 \% \text {, thyroid } 2 \% \text {, prostate } 1 \% \\
\text { and middle ear } 1 \% \text {. }\end{array}$ \\
\hline Merino et al. 1977 [25] & 546 patients with SCC, $21 \%$ OSCC & $\begin{array}{l}\text { primary tumor orally or in the oropharynx: lung } 52 \% \text {, bone } 20.3 \% \text {, } \\
\text { liver } 6 \% \text {, mediastinum } 2.9 \% \text {, lung and bone } 3.3 \% \text { and others } 15.4 \% \text {. } \\
\text { Primary tumor in the nasopharynx: bone } 54 \% \text {, lung } 23.8 \% \text {; primary } \\
\text { tumors of the fossa tonsillaris and of the basis of the tongue: } \\
\text { metastases were primarily found in the liver }(22 \% \text { and } 10.8 \% \\
\text { respectiveliy) }\end{array}$ \\
\hline Papac et al. 1984 [26] & $\begin{array}{l}52 \text { patients with SCC, } 4 \% \text { at the bottom } \\
\text { of the oral cavity, } 10 \% \text { tumors of the } \\
\text { tongue }\end{array}$ & $\begin{array}{l}\text { lung } 75 \% \text {, bone } 44 \% \text {, liver } 17 \% \text {, skin } 13 \% \text {, brain } 13 \% \text {, adrenal } 6 \% \text {, heart } \\
8 \% \text {, kidney } 10 \% \text {, GIT I } 5 \% \text {, mediastinum } 10 \% \text {, spleen } 3 \% \text { and thyroid } \\
6 \% \text {. }\end{array}$ \\
\hline Troell et al. 1995 [27] & $\begin{array}{l}79 \text { patients with SCC with a total of } 145 \\
\text { remote metastases. }\end{array}$ & $\begin{array}{l}\text { lung } 45 \text {, bone } 27 \text {, liver } 11 \text {, mediastinum } 10 \text { and other localisations } \\
\text { (adrenal, brain, pericard, kidney and thyroid) } 7 .\end{array}$ \\
\hline De Bree et al. 2000 [28] & I7 patients with SCC, $34 \%$ OSCC & lung $71 \%$, mediastinum $24 \%$, bone $24 \%$ and liver $6 \%$. \\
\hline Leon et al. 2000 [29] & 64 patients with SCC, $2 \%$ OSCC & $\begin{array}{l}\text { lung/mediastinum } 52 \% \text {, bone } 12 \% \text {, liver } 5 \% \text {, a combination of lung } \\
\text { with bone and liver or skin } 31 \% \text {. }\end{array}$ \\
\hline Kowalski et al. 2005 [30] & $\begin{array}{l}89 \text { patients with distant metastases } \\
\text { coming from oral or oropharyngeal SCC. }\end{array}$ & $\begin{array}{l}\text { lung } 58.4 \% \text {, bone } 37.1 \% \text {, liver } 3.4 \% \text {, brain } 3.4 \% \text {, soft tissue } 2.2 \% \text {, } \\
\text { peritoneum } 1.1 \% \text {, mediastinum } 1.1 \% \text {, axillary lymph nodes } 1.1 \% \text {, lung } \\
\text { combined with bone } 5,6 \% \text {, lung combined with liver } 1.1 \% \text { and lung } \\
\text { combined with brain } 1.1 \% \text {. }\end{array}$ \\
\hline Alvarez Marcos et al. 2006 [3I] & 39 patients with SCC, $26 \%$ OSCC & lung $58 \%$, bone $22 \%$, liver $9 \%$, soft tissue $9 \%$ and others $2 \%$. \\
\hline
\end{tabular}

Abbreviations: $S C C=$ squamous cell carcinoma. 


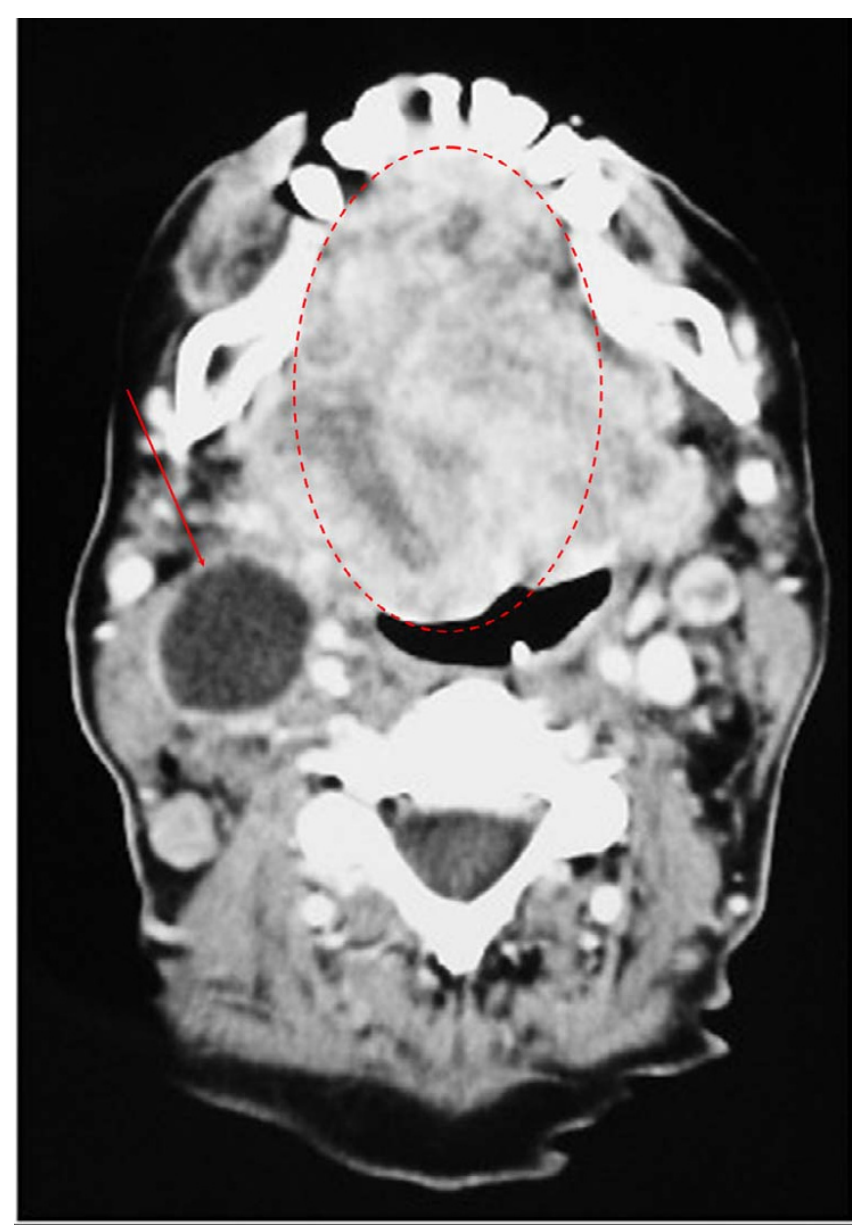

Figure 2

Contrast enhanced CT, soft tissue window: Tumor of the tongue $(10 \mathrm{~cm})$ with a large lymphe node metastasis near the right cervical vessel-nerve-sheath (red arrow).

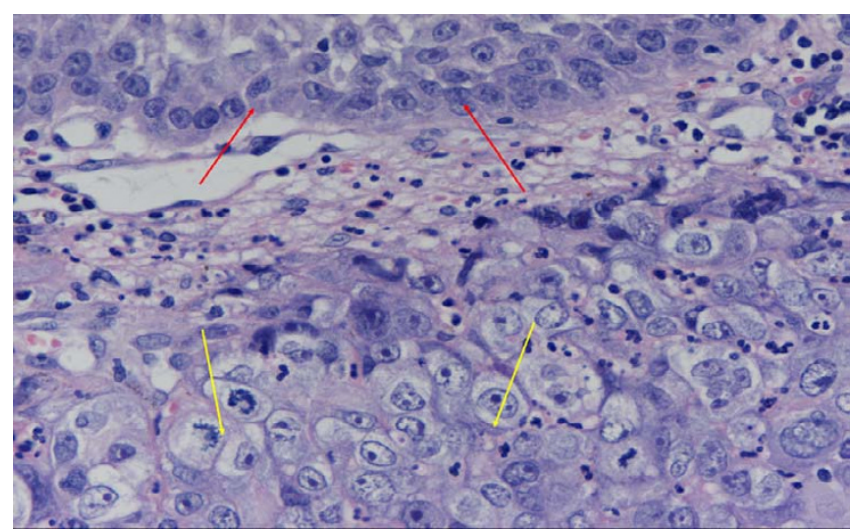

\section{Figure 3}

Histology: normal squamous epithelium (red arrows); carcinoma showing immature cells without keratosis which corresponds to a G3-grading (hematoxylin and eosin (HE) staining; magnification: 100x).

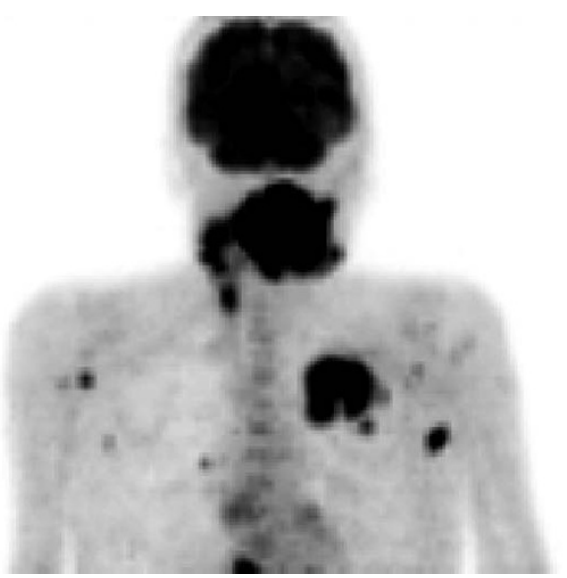

Figure 4

Imaging by fluorine 18-fluoro-2-deoxy-glucose-positron emission tomography (I8F-FDG-PET) anterior-posterior view.

Imaging by fluorine 18-fluoro-2-deoxy-glucose-positron emission tomography (18F-FDG-PET; Fig. 4, 5) scans showed cervical hypermetabolic foci along the nerve-vessel-sheaths of both sides that were suspect for malignancy and assessed as metastases with regard to sensitivity and specifity of PET and CT scan. Multiple metastatic lesions were also present in the lung. Furthermore, foci that were suspect for metastases were also found unilaterally in the muscular system of both the left part of the back and left anterior thoracic wall. On the basis of these rather atypical findings, we performed a total body CT in order to exclude the simultaneous presence of a second malignoma.

Altogether, one suspect soft tissue metastasis could be identified near the left upper ventral thoracal wall (Fig. 6).

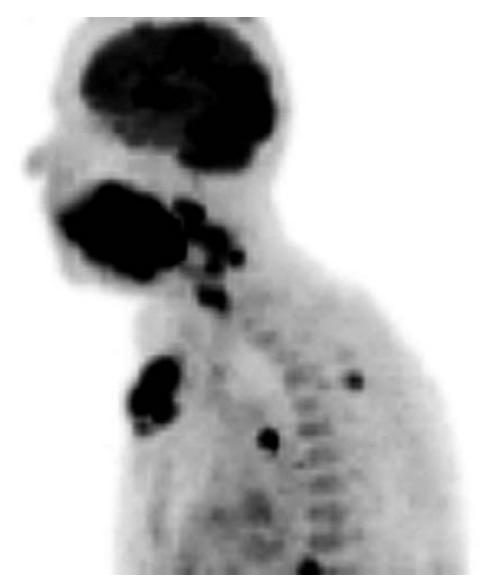

Figure 5

Imaging by fluorine 18-fluoro-2-deoxy-glucose-positron emission tomography (I8F-FDG-PET) lateral view. 


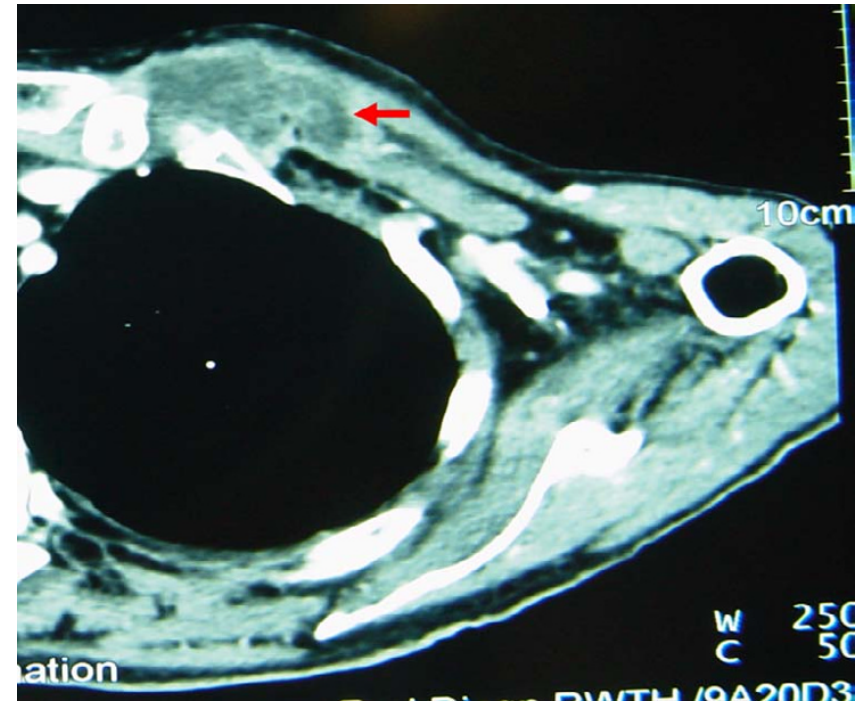

Figure 6

Contrast enhanced CT, soft tissue window: Soft tissue metastasis at the left upper ventral throracic wall.

A further and smaller soft tissue metastasis was found caudal of the sterno-costal base of the first rib in close vicinity to the internal mammary artery. Another metastasis emerged within the thoracic cavity in the right paraaortal soft tissue sheath. A metastasis measuring approximately $1 \mathrm{~cm}$ in diameter was detected in the right iliocostal lumborum muscle near the pelvic rim (Fig. 7). In the right vastus medialis/intermedius muscle one soft tissue

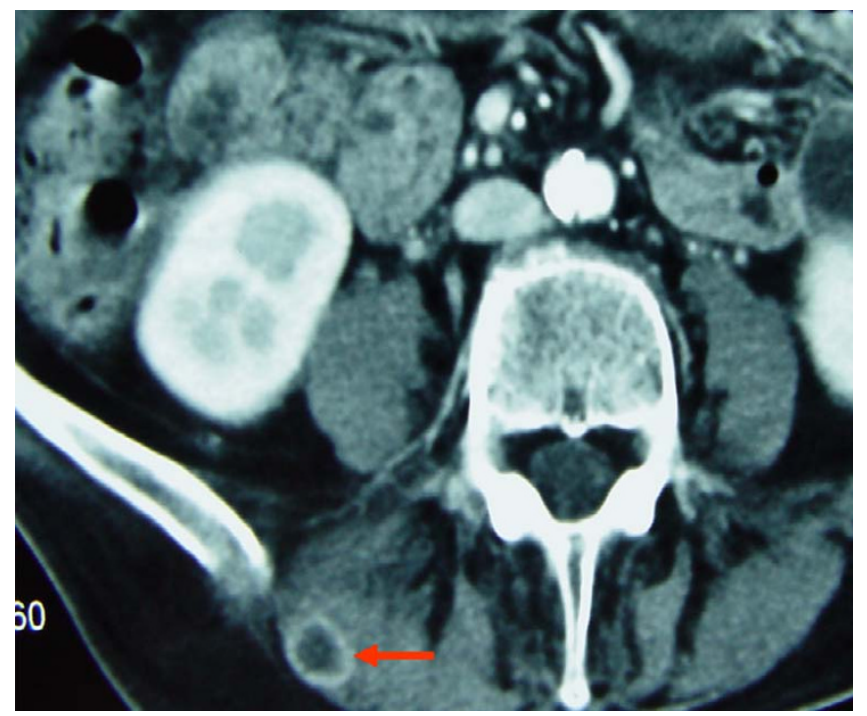

Figure 7

Contrast enhanced CT, soft tissue window: Soft tissue metastasis $(\mathrm{I} \mathrm{cm})$ in the iliocostal lumborum muscle on the right side. metastasis of a diameter of several centimeters was found (Fig. 8). Also, more caudal, a metastasis of approx. $1 \mathrm{~cm}$ in diameter was shown in the right adductor magnus muscle. In the long head of the left biceps femoris muscle another metastasis measuring a few millimeters was identified.

In summary, the tumor staging according to the UICC (Union internationale contre le cancer) revealed a terminal cT4cN3cM1(G3)(C3) tumor. At this advanced stage, surgical therapy with curative intention was not indicated. At the same time, the patient strictly refused a surgical reduction of the tumor, a palliative radiochemotherapy as well as the application of a PEG-device. Therefore, she was transferred to the palliative care unit. The patient finally deceased after 5 weeks of hospitalization by a cardiopulmonary failure as a consequence of the tumor progression. The histologic confirmation of the suspect radiologic diagnoses, which included the spreading of the neoplasia, could be made only for the intraoral findings within the limits of the primary diagnostics, because the patient's relatives did not consent to perform an autopsy despite our request.

\section{Conclusion}

Importantly, in the case presented here, the pattern of an advanced hematogenous spreading of metastases is particular. The metastases were located mainly in the soft tissues of the lower extremities, in particular in the skeletal muscular system. A few small metastasis-like lesions were also found in the cardiopulmonary system, as shown by $18 \mathrm{~F}-$ FDG-PET imaging and CT scans, but they were clearly of

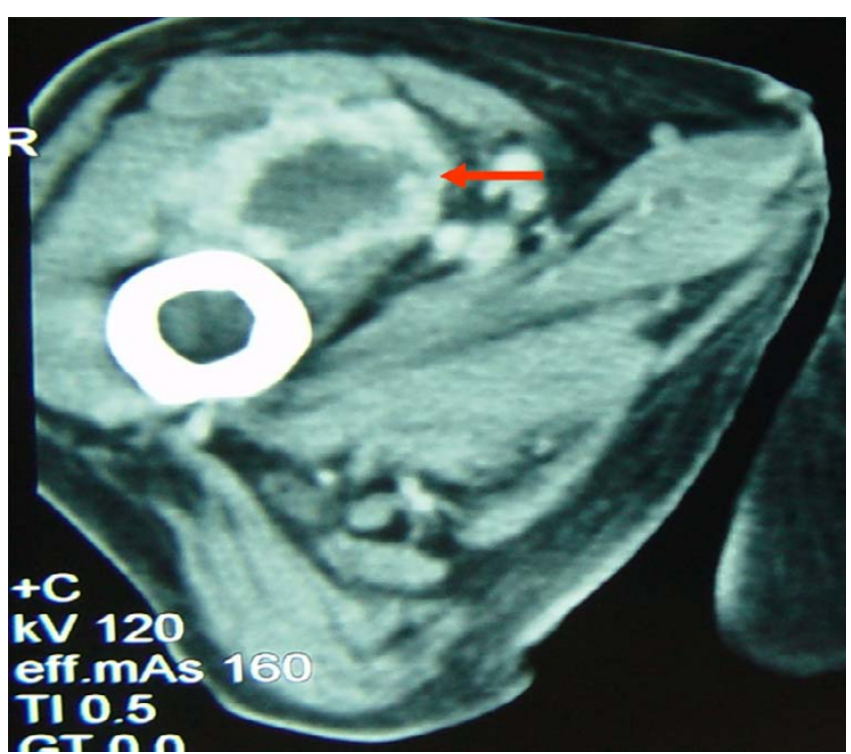

Figure 8

Contrast enhanced CT, soft tissue window: Soft tissue metastasis in the right vastus medialis/intermedius muscles. 
minor extent if compared to the prominent distant metastases in the peripheral skeletal muscles and adjacent soft tissues.

The patient did not show any cardiac lesion in the CT scans. Thus, in case of the presence of masses of unknown origin in the lower extremities in patients who once suffered or are still suffering from a SCC of the oral cavity, a possible spreading of metastases should be taken into consideration. We would like to point out that the examination for such findings should be performed during the continuous tumor recall and control appointments. In the case presented here, a native computertomography of the neck was initially performed. It showed no obstruction or imminent obstruction of the airways. Therefore a tracheotomy was abstained from. In general and in accordance with the current literature, the authors prefer a preoperative tracheotomy in order to avoid postoperative airway difficulties and a tracheotomy in an emergeny setting [6].

In the case of the patient presented here, the quality of life was limited mainly by the tumor of the tongue causing impaired ability to swallow, reduced function of speech and impairment by esthetic and functional disfigurement, three factors that contributed to a low quality of life in a considerable degree. Not the distant metastases were the life-limiting factor, but rather the extensive local findings in the oral cavity which caused considerable respiratory and nutritional limitations. A valuable alternative for patients with a stage IV tumor disease with distant metastases, where the primary tumor is mostly considered to be the survival-limiting factor, is to offer them both an immediate therapy of the primary tumor and an integral palliative care in order to improve the quality of life. Other authors also support these recommendations; e.g., it has recently been shown that patients whose locoregional and remote metastases were operated had a high two-year surviving rate [7]. This kind of tumor-debulking operations cause important defects in the orofacial area and should often be covered by microsurgical flaps. If the patient shows a rather reduced general state of health, any tumor-debulking operation should probably be excerted in a two-timed planning concept to minimize the operative risk. Other authors have recently reported that immediate microsurgical reconstructions could be beneficial in palliative situations $[8,9]$.

It has recently been reported that some patients who suffered an untreated SCC of the head and neck region survived for more than five years. Studies in which the outcome of patients with a SCC who were not treated at all were compared to the outcome of patients who underwent a palliative therapy showed that the mean survival rate was 8.4 months larger in patients who underwent a palliative therapy [10]. However, other authors reported on prolonged surviving rates in some cases of untreated tumors of the head and neck [11-14]. Kowalski and Carvalho $(2000,2001)$ analyzed in a long-lasting retrospective study from 1953 to 1990 the clinical outcome of 808 patients with an untreated tumor of the head and neck $[15,16]$. They reported that, in accordance with the above findings, patients, who did not receive any treatment, survived up to 4 years [16]. Therefore, it seems to be difficult to anticipate the rate of survival by using subjective or objective criteria. The author reports that nearly $50 \%$ of patients with an untreated tumor in the head and neck region deceased within the first four month after the diagnosis had been made and given to the patient. Surprisingly, some patients survived more than four years and the author reported that the factors which had a significant impact on survival were localization of the tumor, tumor staging and scoring the performance of the patients.

Rapoport et al. (1975) compared recurring head and neck tumors in relation to the outcome [17]. One group underwent chemotherapy whereas the control group received a placebo treatment. They concluded that chemotherapy considerably improved the quality of life, but did not prolong the time of survival. New therapeutic strategies such as treatment of head and neck tumors with hyperfractional radiotherapy followed by chemotherapy showed five-year survival rates of more than $40 \%$ [18-20]. In consideration of these survival rates, Kowalski et Carvalho (2001) suggested that new treatment approaches should be offered to all patients and should start as early as possible after having given the diagnosis to the patient. This is important because the mean time period which a transition from a terminal to an untreatable tumor takes is considered to be only 3.8 months [16].

The studies cited here support the ruling opinion that a meticulous staging is an essential aspect within the control of survival rates and quality of life. If the patient, as in the case presented here, refuses biopsy of suspected peripheral metastases, further costs can evolve later when other apparative examination means become necessary. This should be avoided, if possible, by an appropriate early education and guidance of the patient. However, the clinician is often confronted with the delicate task to choose a reasonable balance between minimal and maximal diagnostic means that are available and treat the patient with respect, which is a basic requirement. A PETCT Scan could have been a cost saving, sufficient alternative. According to Nahmias et al. (2007), it shows a specificity of $99 \%$ and a sensitivity of $48 \%$ in a preoperative lymph node staging of the neck with oral squamous cell carcinoma. A positive PET-CT scan has a high positive predictive value [21]. Although the low sensitivity doesn't really help the surgeon in the decision, whicht lymph 
node level has to be removed. Insofar, when planning a neck dissection, the surgeon shoud not depend on the PET-CT scan only. However, there are positive results in detecting remote metastases by PET-CT scans in other studies [22]. Schneider et al. (2006) report on the amenities of the PET-CT scan because of the exact anatomical representation in cases of the CUP-syndrome (cancer of unknown primary-syndrome) in order to find the primary tumor and in the diagnostic of a relapse in tumor aftercare [23]. All the authors mentioned above warn about false positive results, which can have drastic implications on the quality of life of the affected patient. PET-CT Scans are expensive and their use has to be limited to the proper indications. In the years to come, it will be a challenge for the professional medical associations to find consents that are consistent with both saving and optimizing the costs and taking into consideration the individual needs of the patients.

In conclusion, we point out that distant metastases of SCC's of the head and neck region can manifest themselves in the peripheral skeletal muscles and adjacent soft tissues. Therefore, during performing a tumor staging and during aftercare, this possible localization of metastases should be taken into consideration if suspect lesions were found in the peripheral skeletal muscles and nearby soft tissues in a patient who suffers from or who had once suffered from a SCC. It has to be considered that distant metastases of head and neck tumors are probably not the limiting factor for the patient's survival prognosis since the local primary tumors in the oral cavity can importantly impair nutrition and breathing. Therefore, an early operative treatment should be an option for patients suffering from a progressive and terminal head and neck tumor, as a considerable good life expectancy can generally result and as the quality of life can be improved or at least upheld on an acceptable level as long as possible.

\section{Competing interests}

All authors have declared that no competing interests, whether of financial or non-financial nature exist.

\section{Authors' contributions}

RS and OM designed the study. MBG and MH analyzed the data. RS, OM, MBG and MH contributed to writing the paper. DR supervised the clinical treatment and data collection. RS and OM wrote the main part of the paper. All authors gave useful comment on the analysis of data and text of the manuscript.

\section{Consent}

Written informed consent was obtained from the patient for publication of this case report and accompanying images. A copy of the written consent is available for review by the Editor-in-Chief of this journal.

\section{Acknowledgements \\ Funding}

The authors' research was not funded in any way.

\section{References}

I. Rao DN, Shroff PD, Chattopadhyay G, Dinshaw KA: Survival analysis of $\mathbf{5 5 9 5}$ head and neck cancers - results of conventional treatment in a high-risk population. $\mathrm{Br} J$ Cancer 1998, 77:1514-1518.

2. Moriya J, Daimon Y, Itoh Y, Nakano M, Yamada Z: Vegetative cardiac metastases of oral cavity cancer: an autopsy case report. J Cardiol 2004, 44:33-38.

3. Marioni G, Blandamura S, Calgaro N, Ferraro SM, Stramare R, Staffieri A, De Filippis C: Distant muscular (gluteus maximus muscle) metastasis from laryngeal squamous cell carcinoma. Acta Otolaryngol 2005, I 25:678-682.

4. Oo AL, Yamaguchi S, Iwaki H, Amagasa T: Axillary nodal metastasis from oral and maxillofacial cancers: a report of 3 cases. J Oral Maxillofac Surg 2004, 62: 1019-1024.

5. Mess D, Songer M: Head and neck carcinoma metastases to the hand and foot. A case report of simultaneous involvement. Orthopedics 1986, 9:975-977.

6. Eipe N, Choudhrie A, Dildeep Pillai A, Choudhrie R: Elective preoperative tracheostomy for head and neck oncoplastic surgery. Acta Anaesthesiol Scand 2006, 50:523-524.

7. Malone JP, Stephens JA, Grecula JC, Rhoades CA, Ghaheri BA, Schuller DE: Disease control, survival, and functional outcome after multimodal treatment for advanced-stage tongue base cancer. Head Neck 2004, 26:56I-572.

8. Bedogni A, Ragazzo M, Chiarini L, Nocini PF: Use of a combined protocol to treat bisphosphonate-associated jawbone osteomyelitis: a I2-month follow-up. J Cranio-Maxillofac Surg 2006, 34(Suppl I):34.

9. Boyd JB, Morris S, Rosen IB, Gullane P, Rotstein L, Freeman JL: The through-and-through oromandibular defect: rationale for aggressive reconstruction. Plast Reconstr Surg 1994, 93:44-53.

10. Burns L, Chase D, Goodwin WJ Jr: Treatment of patients with stage IV cancer: do the ends justify the means? Otolaryngol Head Neck Surg 1987, 97:8-I4.

II. Shimkin MB: Duration of life in untreated cancer. Cancer 195I, 4:I-8.

12. Shimkin MB, Griswold MH, Cutler SJ: Classics in oncology. Survival in untreated and treated cancer. CA Cancer J Clin 1984, 34:282-294.

13. Stell PM: Survival times in end-stage head and neck cancer. Eur J Surg Oncol 1989, 15:407-410.

14. Welch CE, Nathanson IT: Life expectancy and incidence of malignant disease. II. Carcinoma of the lip, oral cavity, larynx and antrum. Am / Cancer 1937, 31:238-252.

15. Kowalski LP, Carvalho AL: Natural history of untreated head and neck cancer. Eur J Cancer 2000, 36: 1032-1037.

16. Kowalski LP, Carvalho AL: Influence of time delay and clinical upstaging in the prognosis of head and neck cancer. Oral Oncol 2001, 37:94-98.

17. Rapoport A, Sobrinho JA, Junior JS, Cubrero JD: Bleomycin on head and neck cancer treatment. Rev Bras Circ Cab Pesc 1975, 2:69-83.

18. Dobrowsky W, Naude J, Widder J, Dobrowsky E, Millesi W, Pavelka $\mathrm{R}$, Grasl C, Reichel M: Continuous hyperfractionated accelerated radiotherapy with/without mitomycin $C$ in head and neck cancer. Int J Radiat Oncol Biol Phys 1998, 42:803-806.

19. El-Sayed S, Nelson N: Adjuvant and adjunctive chemotherapy in the management of squamous cell carcinoma of the head and neck region. A meta-analysis of prospective and randomized trials. J Clin Oncol 1996, 14:838-847.

20. Jeremic B, Shibamoto Y, Stanisavljevic B, Milojevic L, Milicic B, Nikolic $N$ : Radiation therapy alone or with concurrent low-dose daily either cisplatin or carboplatin in locally advanced unresectable squamous cell carcinoma of the head and neck: a prospective randomized trial. Radiother Oncol 1997, 43:29-37.

21. Nahmias C, Carlson ER, Duncan LD, Blodgett TM, Kennedy J, Long MJ, Carr C, Hubner KF, Townsend DW: Positron emission tomography/computerized tomography (PET/CT) scanning for 
preoperative staging of patients with oral/head and neck cancer. J Oral Maxillofac Surg 2007, 65:2524-2535.

22. Schneider K, Aschoff Ph, Bihl H, Hagen R: Das integrierte PET/ CT: Technischer Fortschritt in der Diagnostik von KopfHals-Karzinom-Rezidiven und CUP? Laryngo-Rhino-Otol 2006, 85:179-183.

23. Von Schulthess GK, Pelc NJ: Integrated-Modality Imaging: The Best of Both Worlds. Acad Radiol 2002, 9:124I-I244.

24. Probert JC, Thompson RW, Bagshaw MA: Patterns of spread of distant metastases in head and neck cancer. Cancer 1974, 33:127-133.

25. Merino OR, Lindberg RD, Fletcher GH: An analysis of distant metastases from squamous cell carcinoma of the upper respiratory and digestive tracts. Cancer 1977, 40:145-151.

26. Papac RJ: Distant metastases from head and neck cancer. Cancer 1984, 53:342-345.

27. Troell RJ, Terris DJ: Detection of metastases from head and neck cancers. Laryngoscope 1995, 105:247-250.

28. de Bree R, Deurloo EE, Snow GB, Leemans CR: Screening for distant metastases in patients with head and neck cancer. Laryngoscope 2000, I I 0:397-40I.

29. Leon X, Quer M, Orus C, del Prado Venegas M, Lopez M: Distant metastases in head and neck cancer patients who achieved loco-regional control. Head Neck 2000, 22:680-686.

30. Kowalski LP, Carvalho AL, Martins Priante AV, Magrin J: Predictive factors for distant metastasis from oral and oropharyngeal squamous cell carcinoma. Oral Oncol 2005, 41:534-54I.

31. Alvarez Marcos CA, Llorente Pendas JL, Franco Gutierrez V, Hermsen M, Cuesta Albalad MP, Fernandez Espina H, Suarez Nieto C: Distant metastases in head and neck cancer. Acta Otorhinolaringol Esp 2006, 57:369-372.

Publish with Bio Med Central and every scientist can read your work free of charge

"BioMed Central will be the most significant development for disseminating the results of biomedical research in our lifetime. "

Sir Paul Nurse, Cancer Research UK

Your research papers will be:

- available free of charge to the entire biomedical community

- peer reviewed and published immediately upon acceptance

- cited in PubMed and archived on PubMed Central

- yours - you keep the copyright

Submit your manuscript here:

http://www.biomedcentral.com/info/publishing_adv.asp 